\title{
NUTRITIONAL CHARACTERISTICS OF AMAZONIAN FISH FAT (Colossoma macropomum) AND ITS EFFECT ON LIPID METABOLISM OF RATS FED HYPERCHOLESTEROLEMIC DIETS ${ }^{1}$
}

\author{
Raimundo Vicente de SOUSA ${ }^{2}$, Paulo César Ferreira SANTOS ${ }^{3}$, Eduardo Alues BAMBIRRA ${ }^{4}$, \\ Enio Cardillo VIEIRA ${ }^{3}$, Jacqueline Isaura ALVAREZ-LEITE ${ }^{3, *}$
}

\begin{abstract}
SUMMARY
The effects of fat from tambaqui (Colossoma macropomum), an Amazonian fish, on some nutritional and lipid parameters in rats were evaluated. Weaned Wistar rats were fed for 6 weeks with hypercholesterolemic diets containing $7.5 \%$ of soybean oil (SO), cod liver oil (CO), lard (LA), or tambaqui fat (TF). Food consumption, weight gain, and food conversion were measured weekly. Plasma triglycerides was determined at the beginning and on the $6^{\text {th }}$ week of experiment. Plasma cholesterol was determined at $0,2,4$ and 6 weeks. After the sacrifice, hepatic lipids (triglycerides and cholesterol) and plasma triglycerides, total cholesterol and HDL fractions were determined. Food consumption and weight gain were the same for all groups. There were no differences in plasma triglycerides among the four groups in the $1^{\text {st }}$ and $6^{\text {th }}$ weeks. Regarding the cholesterolemia, TF animals were similar to those fed SO diet, significantly lower than in LA group but higher compared to the $\mathrm{CO}$ group. The levels of very low density lipoprotein + low density lipoprotein (VLDL+LDL) were higher in the TF and LA groups compared to the CO and SO groups. However, TA fed animals had high-density lipoprotein (HDL) cholesterol levels higher than the CO group. The ratio (VLDL+LDL)/HDL was higher in the LA group when compared with the remaining groups. In the TA group, the triglycerides and cholesterol concentrations in the liver were similar to the SO group. It may be concluded that tambaqui fat is a good dietary source of lipids as a substitute for lard and similar to soybean oil, as far as atherosclerosis risks is concerned.

Keywords: dietary fish oil; cholesterol; rats; lipid metabolism.
\end{abstract}

\section{RESUMO}

CARACTERÍSTICAS NUTRICIONAIS DO TAMBAQUI (COLOSSOMA MACROPOMUM) E SEU EFEITO NO METABOLISMO LIPÍDICO DE RATOS ALIMENTADOS COM DIETAS RICAS EM COLESTEROL. Os efeitos da ingestão da gordura de Tambaqui (Colossoma macropomum) foram analisados em relação a alguns parâmetros nutricionais e lipídicos. Para isso ratos Wistar recém desmamados alimentados por 6 semanas com dietas aterogênicas contendo $7,5 \%$ óleo de soja (SO), óleo de figado de bacalhau (CO), sebo (LA), ou gordura de Tambaqui (TF) foram utilizados. Consumo alimentar e ganho de peso foram medidos semanalmente. Triglicérides séricos foram determinados no início do experimento. Colesterol plasmático foi determinado no início, $2^{\mathrm{a}}$ e $4^{\mathrm{a}}$ semanas do experimento. Após o sacrificio, colesterol e triglicérides hepáticos, triglicérides, colesterol séricos foram determinados. Os resultados mostram consumo alimentar e ganho de peso semelhante em todos os grupos. Não houve diferenças na trigliceridemia entre os 4 grupos no início e $6^{a}$ semana do experimento. Em relação à colesterolemia, animais do grupo TF tiveram niveis de colesterol semelhantes aos do grupo SO, significantemente mais baixos que no grupo LA e mais altos comparados ao grupo CO. Os niveis de colesterol em LDL + VLDL foram mais altos nos animais do grupo TF e LA comparados aos grupos CO e SO. Entretanto, animais do grupo TA tiveram HDL mais alto que animais do grupo CO. A taxa (VLDL+LDL)/HDL foi mais alta nos animais do grupo LA quando comparados com os demais grupos. Nos animais do grupo TA, as concentrações de triglicérides e colesterol hepáticos foram similares ao do grupo SO. Nós concluimos que a gordura de Tambaqui é uma boa fonte alimentar de lipides e pode ser usada como substituto de gordura da carne bovina, com efeitos similares ao óleo de soja quando os fatores de risco de aterosclerose são considerados.

Palavras-chave: gordura alimentar de peixe, colesterol, ratos, metabolismo lipídico.

\section{INTRODUCTION}

Lipid-rich diets have been associated with several diseases, especially coronary heart disease (CHD) [30]. Both the quality and the quantity of dietary lipids are important in the prevention of CHD [14]. Epidemiological studies of the seventies [6] have shown that dietary polyunsaturated lipids exert some protection against the development of atherosclerosis as well as a high consumption of marine products, as shown for populations from the west coast of Greenland [24] and from some islands of the Pacific Ocean [9]. In addition, some protection is attributed to olive oil (rich in monounsaturated fatty acids) based on data for some
Mediterranean countries [21,22]. High consumption of saturated fatty acids is directly correlated with a high incidence of CHD $[14,18,19]$.

Most unsaturated fatty acids belong to one of the three families: $\mathrm{w}-9, \mathrm{w}-6$, and $\mathrm{w}-3$, whose parent compounds are: oleic (18:1 $\omega-9)$, linoleic $(18: 2 \omega-6)$, and linolenic acid (18:3 $\omega-3)$, respectively. Examples of dietary sources of $\omega-9, \omega-6$, and $w-3$ are olive, soybean, and fish oils, respectively. The protection conferred by fish oil is attributed both to a reduction of triglyceride synthesis in liver and, consequently, a diminished secretion of VLDL [19] and to a modification of the eicosanoid secretion pattern [9].

${ }^{1}$ Recebido para publicação em 13/06/01. Aceito para publicação em 30/10/01.

${ }^{2}$ Depto de Zootecnia. Universidade Federal de Lavras, Lavras, MG, Brasil.

${ }^{3}$ Depto de Bioquimica e Imunologia, Instituto de Ciências Biológicas. UFMG. Caixa Postal 486, CEP 30161.970. Belo Horizonte, MG, Brasil. Fone: 5531 34992652, Fax 5531 34415963.E-mail: alvarez@mono.icb.ufmg.br

${ }^{4}$ Depto de Anatomia Patológica, Faculdade de Medicina. Universidade Federal de Minas Gerais (UFMG), Caixa Postal 486, CEP 30161-970 Belo Horizonte, MG, Brasil.

* A quem a correspondência deve ser enviada. 
Fish have a high variety of fatty acids and amount of cholesterol in their lipids [16, 17]. Fish oil is a byproduct, which can be used for medicinal purposes or incorporated in rations for animals. Tambaqui (Colossoma macropomum) is a fish species found in rivers of tropical areas. In the Amazon region, the intraabdominal fat of tambaqui is used by people as a source of fat in diet from many groups replacing vegetal oils or animal fat [4.5]. Fish from rivers have a low concentration of $\omega$-3 fatty acids compared to marine fish. MAIA, RODRIGUEZ-AMAYA [20] analysed the fat composition of tambaqui fillets. They showed that total lipid (6\%) consisted of $90.7 \%$ of neutral lipids and $8.7 \%$ phospholipids. The principal fatty acids found by GCMS were 18:1 $\omega-9$ (40\%), 16:0 (28.8\%), 18:0 (9.8\%), $18: 2 \omega-6(8.9 \%)$ and $16: 1 \omega-7(6.3 \%)$. The saturated, monoenoic, dienoic and polyunsaturated fatty acids accounted for $40.2 ; 47.5,8.9$ and $2.5 \%$, respectively. Besides, the rate of $\omega-6 / \omega-3$ is very low $(0.1 \%)$ with only $0.9 \%$ of the mainly fatty acids $\omega-3$.

The effect of tambaqui fat in cholesterol metabolism is not yet established. This work aims at the evaluation of the effect of tambaqui on lipid metabolism in rats.

\section{2 - MATERIALS AND METHODS}

\section{1 - Animals and diets}

Four weeks old Wistar male rats were divided into four groups of 10 animals. They were housed in individual cages. Water and food were provided ad libitum and measured weekly for food conversion determination.

Table 1 shows the composition of the diets, which were isoproteic and isocaloric and varied only in the source of lipids: soybean oil, cod liver oil, tambaqui fat, or lard at $7.5 \%$ level. The diets were prepared every two weeks and the lipids were added in portions enough for one week. The diets were stored at $-10^{\circ} \mathrm{C}$ and supplied every night to avoid exposure to light and oxidative damage to the lipids.

TABLE 1. Composition (g/100g) of hypercholesterolemic diets. Four groups of 10 weaned rats were fed for 6 weeks on diets containing $7.5 \%$ of soybean oil (SO), cod liver oil (CO), lard (LA), or tambaqui fat (TF).

\begin{tabular}{|c|c|c|c|c|}
\hline COMPONENT & SO DIET & CO DIET & TF DIET & LA DIET \\
\hline Casein & 20.00 & 20.00 & 20.00 & 20.00 \\
\hline Sucrose & 10.00 & 10.00 & 10.00 & 10.00 \\
\hline $\operatorname{Starch}^{1}$ & 51.78 & 51.78 & 51.78 & 51.78 \\
\hline Soybean oil & 7.50 & - & - & - \\
\hline Cod liver oil ${ }^{2}$ & - & 7.50 & - & - \\
\hline Tambaqui fat ${ }^{3}$ & - & - & 7.50 & - \\
\hline Lard (swine) & - & - & - & 7.50 \\
\hline Cellulose & 5.00 & 5.00 & 5.00 & 5.00 \\
\hline Mineral mixture ${ }^{4}$ & 3.50 & 3.50 & 3.50 & 3.50 \\
\hline Vitamin mixture ${ }^{4}$ & 1.00 & 1.00 & 1.00 & 1.00 \\
\hline Coline & 0.20 & 0.20 & 0.20 & 0.20 \\
\hline Methionine & 0.30 & 0.30 & 0.30 & 0.30 \\
\hline Cholesterol $^{5}$ & 0.50 & 0.50 & 0.50 & 0.50 \\
\hline sodium colate $^{5}$ & 0.20 & 0.20 & 0.20 & 0.20 \\
\hline Vitamin $\mathrm{E}$ & 0.01 & 0.01 & 0.01 & 0.01 \\
\hline BHT $^{6}$ & 0.01 & 0.01 & 0.01 & 0.01 \\
\hline
\end{tabular}

\section{2 - Iodine and saponification values}

Iodine and saponification values were determined according to A.O.A.C [1].

\section{3 - Total cholesterol and triglycerides in plasma or serum}

Total cholesterol and triglycerides were determined with kits using cholesterol oxidase and glycerophosphate oxidase methods (KATAL, Brazil), respectively. Blood was drawn from the orbital plexus at the beginning of the experiment and weekly with 4\% EDTA in capillary tubes. Plasma was separated by centrifugation $(3000 \mathrm{rpm}, 10$ minutes). At the end of the experiment, blood was drawn from the axillary plexus without anticoagulant and the serum was obtained.

\section{4 - Determination of cholesterol in lipoproteins}

HDL-cholesterol (HDLc) was determined after selective and quantitative precipitation with phosphotungstic acid (Boehringer - USA) of LDL and VLDL. After centrifugation, cholesterol was determined in the supernatant through the cholesterol oxidase method. The cholesterol in LDL and VLDL fractions (VLDL+LDLc) was calculated as the difference between total and HDLcholesterol.

\section{5 - Determination of moisture and lipid fractions in liver and adipose tissue}

An aliquot of $3 g$ of liver and adipose tissue was used for lipid extraction with ethyl ether in a Sohxlet apparatus for 8 hours, dried in a ventilated oven at $60^{\circ} \mathrm{C}$ for 6 hours and then transferred to an oven at $105^{\circ} \mathrm{C}$ for 6 hours. Moisture was determined by difference in weights. For the hepatic determination of triglycerides and cholesterol, an aliquot of 50mg of tissue was extracted according to the method of FOLCH, LEES, STANLEY [7]. The resulting extract was resuspended in $500 \mathrm{~mL}$ of isopropanol and run in an activated $\left(200^{\circ} \mathrm{C}\right.$ for two hours) silica gel column, re-extracted with ethyl ether, evaporated and re-suspended in isopropanol. Triglycerides and cholesterol were determined in these aliquots using the same enzymatic kits used for serum determination. The same procedure was used for triglyceride and cholesterol determination in adipose tissue.

\section{6 - Histologic analysis}

Fragments of liver were fixed in 4\% formaldehyde and embedded in paraffin. Histological sections (3-5 $\mu \mathrm{m})$ were stained with hematoxylin-eosin and periodic acid Schiff and examined by a single observer who was unaware of the code for animal identification, with the groups being identified only after the elaboration of the histopathological report.

\section{7 - Statistical analysis}

The data were submitted to analysis of variance. The minimum significant difference was found through the 
calculations of the variance of error and the values obtained from the $\mathrm{T}$ distribution [27].

\section{3 - RESULTS AND DISCUSSION}

\section{1 - Iodine and saponification values}

Table 2 shows that tambaqui fat had the lowest saponification value and an iodine value intermediate between soybean oil and swine lard.

TABLE 2. Iodine and saponification values of lard, tambaqui fat, soybean oil and cod liver oil used in experimental diets.

\begin{tabular}{ccccc}
\hline Value & Tambaqui fat & Soybean oil & Cod liver oil & Lard \\
\hline Iodine $^{*}$ & $98.65(2.66)$ & $126.12(8.97)$ & $169.35(8.08)$ & $65.65(2.66)$ \\
Saponification $^{*}$ & $184.94(0.32)$ & $204.34(4.96)$ & $205.69(4.96)$ & $210.83(0.85)$ \\
\hline
\end{tabular}

Mean (Standard Deviation) from 10 rats.

\section{2 - Food intake, food conversion, and weight gain and liver weight}

There was no significant difference in weight gain and food intake among the different groups. On the other hand, the group fed on lard had a significantly worse food conversion when compared with the groups fed on soy or cod liver oil (Table 3).

TABLE 3. Weight gain, food intake and food conversion of rats fed on diets containing $7.5 \%$ of tambaqui fat (TF), cod liver oil (CO), soybean oil (SO) or lard (LA) for 6 weeks.

\begin{tabular}{lccc}
\hline Group & Weight gain (g/day) & Food Intake(g/day) & Food conversion \\
\hline Tambaqui fat & $4.61(0.56)^{*}$ & $14.96(0.52)$ & $3.26(0.23)^{\mathrm{ab}}$ \\
Soybean oil & $4.73(0.58)$ & $14.61(1.24)$ & $3.10(0.23)^{\mathrm{a}}$ \\
Cod liver oil & $4.68(0.40)$ & $14.76(0.63)$ & $3.16(0.20)^{\mathrm{a}}$ \\
Lard & $4.21(0.67)$ & $14.80(0.95)$ & $3.55(0.31)^{\mathrm{b}}$ \\
\hline
\end{tabular}
different $(\mathrm{p}<0.05)$

No significant differences were found in liver weight and in the ratio liver weight/body weight among the four groups.

\section{3 - Blood lipids}

There were no significant differences in the levels of triglycerides among the four groups in the $1^{\text {st }}$ and $6^{\text {th }}$ weeks (Table 4).

TABLE 4. Plasma triglycerides and cholesterol (mg/100mL) of four groups of 10 weaned rats fed on diets containing $7.5 \%$ of tambaqui fat (TF), soybean oil (SO), cod liver oil (CO) or lard (LA) for 6 weeks.

\begin{tabular}{rllll}
\hline & \multicolumn{1}{r}{ TF DIET } & \multicolumn{1}{c}{ SO DIET } & \multicolumn{1}{c}{ CO DIET } & LA DIET \\
\hline Triglyceride & & & & \\
Initial & $87.69(10.75)$ & $121.23(22.57)$ & $127.95(5.5)$ & $84.85(8.29)$ \\
$\mathbf{6}^{\text {th }}$ week & $97.94(8.15)$ & $115.65(21.16)$ & $70.51(5.33)$ & $90.72(7.87)$ \\
Cholesterol & & & & \\
Initial & $88.40(5.76)$ & $80.88(4.33)$ & $81.40(6.04)$ & $90.78(7.31)$ \\
$\mathbf{2}^{\text {nd }}$ week & $249.44(14.31)^{\mathbf{a}}$ & $217.33(11.92)^{\mathbf{a}}$ & $146.75(8.16)^{\mathbf{b}}$ & $305.56(14.07)^{\mathbf{c}}$ \\
$\mathbf{4}^{\text {th }}$ week & $190.11(14.33)^{\mathbf{a}}$ & $157.80(5.04)^{\mathbf{a}}$ & $100.78(10.24)^{\mathbf{b}}$ & $299.00(28.26)^{\mathbf{c}}$ \\
$\mathbf{6}^{\text {th }}$ week & $180.84(15.01)^{\mathbf{a}}$ & $131.41(9.57)^{\mathbf{b}}$ & $96.95(6.94)^{\mathbf{b}}$ & $227.86(11.89)^{\mathbf{c}}$ \\
\hline
\end{tabular}

Mean (Standard Deviation) from 10 rats. Values with different letters in the same week are significantly different $(p<0.05)$.
The cholesterolemia of tambaqui fat fed animals was similar to those fed soybean oil diet, significantly lower than in the group fed on lard throughout the experiment but higher compared to animals fed on cod liver oil.

Regarding the levels of cholesterol in the different lipoprotein fractions, the rats fed on a diet containing tambaqui fat had, statistically (Table 5): (1) higher levels of LDL+VLDL than animals fed on soybean or cod liver oils but similar levels to animals fed on lard; (2) higher levels of HDL than the group fed on lard. The ratio LDL + VLDL/HDL was higher in the group fed on lard than in the remaining groups.

TABLE 5. Cholesterol (mg/dl) in HDL (HDLc) and in LDL+VLDL (LDL+VLDL)c, and (LDL+VLDL)c/HDLc ratio of four groups of 10 weaned rats fed on diets containing $7.5 \%$ of tambaqui fat (TF), soybean oil (SO), cod liver oil (CO) or lard (LA) for 6 weeks.

\begin{tabular}{cccc}
\hline Group & $(\mathbf{L D L}+\mathbf{V L D L}) \mathbf{c}$ & HDLc & $(\mathbf{L D L}+\mathbf{V} \mathbf{L} \mathbf{c}) \mathbf{c} /$ HDLc \\
\hline TF & $151.33(15.57)^{\mathbf{a}^{\mathbf{a}}}$ & $38.35(4.14)^{\mathbf{a}}$ & $4.06(0.51)^{\mathbf{a}}$ \\
SO & $99.33(9.18)^{\mathbf{b}}$ & $39.57(4.20)^{\mathbf{a}}$ & $2.77(0.38)^{\mathbf{a}}$ \\
CO & $75.52(7.27)^{\mathbf{b}}$ & $22.18(2.14)^{\mathbf{b}}$ & $3.30(0.49)^{\mathbf{a}}$ \\
LA & $189.88(12.40)^{\mathbf{a}}$ & $29.75(1.70)^{\mathbf{a b}}$ & $6.64(0.68)^{\mathbf{b}}$ \\
\hline
\end{tabular}

" Mean \pm (Standard Deviation) from 10 rats. Values with different letters in the same column are significantly different $(\mathrm{p}<0.05)$.

\section{4 - Liver and adipose tissue lipids}

No significant difference was found when the group fed on tambaqui fat was compared with the other groups. Ether extracted materials were lower only in the group fed on soybean group compared with the cod liver oil group. The hepatic cholesterol concentration was higher in the cod oil compared with the lard group. No significant difference was found between the other groups. The levels of triglycerides were higher in the group fed on lard than in the groups fed on soybean oil or cod liver oil. The cholesterol levels in adipose tissue were statistically the same in all groups (Table 6).

\section{5 - Histological evaluation}

No histological alterations could be detected with the different dietary treatments (data not shown).

\section{6 - Discussion}

The degree of unsaturation of tambaqui fat is intermediate between lard and soybean oil (Table 2). The iodine value reported here is above the value reported by CASTELO, AMAYA, STRONG [5] who analysed several samples of intra abdominal fat of the fish, captured in different months. The saponification value found (Table 2) is the same reported by CASTELO, AMAYA, STRONG [5]. The differences in the saponification values for the different products may be credited to varied content in unsapanonifiable matter (cholesterol and other steroids, pigments, hydrocarbons and aliphatic alcohols).

The weight gain of the rats (Table 3) was similar for all groups and normal for the Wistar strain [11]. However, in spite of the fact that the food intake and weight gain were the same, the food conversion was significantly 
worse in the group fed on lard when compared with the groups fed on either soybean or cod liver oils. Since the diets were isoproteic and isocaloric, this may be due to a lower digestibility of lard (rich on saturated fatty acid) compared with the two other fat sources. The group fed on tambaqui fat showed no difference in food conversion when compared with the remaining groups. This might be due to the levels of saturated $(40 \%)$ and unsaturated fatty acids (60\%) [20], which could reduce the digestibility of tambaqui fat compared with cod liver and soybean oils but improving it compared with the lard group.

Dietary tambaqui fat did not affect the levels of triglycerides in blood (Table 4). TAKITA, NAKAMURA, INAMI [29] showed that rats fed for two weeks with $\omega-3$ fatty acids from different sources had lower blood triglyceride levels in relation to lard. This effect was more pronounced if eicosapentaenoic acid (EPA) was the source of fatty acid and if the $\omega-3 / \omega-6$ ratio was increased. Animals of our cod liver oil group had the lowest triglyceridaemia but it was not significantly different. EPA is not found in tambaqui fat [5]. Our results did not show any modifications on triglyceridaemia of rats fed on different diets after 6 weeks of experiment.

Tambaqui fat diets had an intermediate effect on serum cholesterol: it reduced the hypercholesterolemic effect seen in the lard fed group but induced higher levels than cod liver oil fed groups. Considering the whole experiment, the effect of tambaqui fat on serum cholesterol resembles that of soybean oil (Table 4) even though its composition approaches that of lard [5]. This might be the consequence of the high levels of monounsaturated fatty acid in the tambaqui fat composition (almost $40 \%$ of total fatty acids) which has a hypocholesterolemic effect when it is used as a substitute for lard in many experimental diets [5]. The group fed on cod liver oil had significant lower levels of cholesterol than the other groups (Table 4). This is in agreement with the results reported by YAQOOB et al. [33] for rats fed on menhaden oil for 10 weeks. The more pronounced cholesterol-lowering effect of cod liver oil may be explained by its high content in eicosapentaenoic and dodecosahexenoic acids [29]. The properties of $\omega-6$ and $\omega-3$ fatty acids on lowering the blood levels of cholesterol is attributed to their effects on: (1) modulation of certain enzymatic systems related to the biosynthesis of cholesterol; (2) rate of cholesterol esterification in liver; (3) reduction of pancreatic secretion of apolipoproteins; (4) rise in the biliary pool of cholesterol [3, 26, 32]. Our results are in according with those published by OLIVEIRA [23], showing that total cholesterolemia were significantly lower in rats fed on marine fish oil as compared with animals fed on corn oil or sweet water Brazilian fishes. These data are reinforced by other authors showing small quantities of $\omega$-3 (less than $2 \%$ ) on tambaqui fat and a general rate $\omega-3 / \omega-6$ of 0.1 [20].

The LDL+VLDLc concentrations found in rats of tambaqui fat group were comparable to that seen in lard fed rats and higher than that in cod liver and soybean oil fed groups (Table 5). These high levels in rats fed on tambaqui fat and lard-containing diet is related to the high content in saturated fatty acids which can induce the hepatic synthesis of VLDL as well as inhibit the hepatic uptake of remnants of VLDL metabolism [10, $15,28]$. However, HDLc was significantly higher in rats fed either on soybean oil or tambaqui fat containing diet when compared with animals fed on cod liver oil. The (VLDL +LDL)/HDL ratio was statistically the same as those obtained for animals fed on soybean oil or cod liver oil containing diet suggesting a better effect of tambaqui fat intake on cholesterol profile than lard intake. Several authors [8, 12, 25, 26, 31] have already reported the effect of fish oils rich in $\omega-3$ in lowering LDL- and HDL-cholesterol.

The concentration of total lipids in the liver was higher in rats fed on cod liver oil than those fed on soybean oil (Table 5), which is in agreement with the findings reported by YAQOOB et al. [33] who compared menhaden oil with some vegetable oils. The activities of glycerophosphate acyl transferase and diacilglycerol acyl transferase - key enzymes in the biosynthesis of triglycerides - are raised in the liver of rats fed on a cholesterol-supplemented diet [19]. Rats treated with a diet rich in $\omega-3$ fatty acids for three weeks had a drop of $41 \%$ in triglyceride levels in plasma due to a decrease in the hepatic synthesis of triglycerides; this drop paralleled to a $26 \%$ reduction in the activity of phosphatidate phosphohydrolase, an important enzyme in the regulation of biosynthesis of triglycerides [2]. The levels of triglycerides were significantly higher in the rats fed on lard than in those fed either on the soybean or cod liver oils (Table 5). These results may be explained by the induction of the synthesis of VLDL in liver by saturated fatty acids. YAQOOB et al. [33] found that the composition in fatty acids of blood and different tissues and organs simulates that of diet, except for brain and heart where the proportions of fatty acids are relatively conserved.

The cholesterol levels in liver are inversely proportional to those of blood. This may be due to a modulation of VLDL synthesis as well as to a higher uptake of chylomicron remnants and IDL by the hepatocytes from animals fed on a lipid source where the ratio of polyunsaturated/saturated fatty acids is high leading to a rise in cholesterol in this organ. Some authors $[9,10]$ relate the higher uptake of chylomicron remnants to its higher fluidity due to the presence of polyunsaturated fatty acids. A reverse reasoning explains the elevation of serum cholesterol by mechanisms that stimulate the synthesis of VLDL.

TABLE 6. Hepatic triglycerides, cholesterol and ether extracted (EE) material (mg/g liver) of four groups of 10 weaned rats fed on diets containing $7.5 \%$ of tambaqui fat $(\mathrm{TF})$, soybean oil (SO), cod liver oil (CO) or lard (LA) for 6 weeks

\begin{tabular}{crlll}
\hline & \multicolumn{1}{c}{ TF DIET } & \multicolumn{1}{c}{ SO DIET } & \multicolumn{1}{c}{ CO DIET } & LA DIET \\
\hline Triglyceride & $30.01(2.11)^{\mathrm{a}} \mathrm{ab}$ & $19.15(1.30)^{\mathrm{a}}$ & $25.65(1.67)^{\mathrm{a}}$ & $52.74(3.85)^{\mathrm{b}}$ \\
Cholesterol & $18.97(1.25)^{\mathrm{ab}}$ & $20.21(1.38)^{\mathrm{ab}}$ & $29.35(2.00)^{\mathrm{a}}$ & $14.45(0.89)^{\mathbf{b}}$ \\
$\mathbf{E E}^{1}$ & $51.53\left(0.97^{\mathrm{ab}}\right.$ & $46.82(1.61)^{\mathrm{a}}$ & $55.61(0.8)^{\mathbf{b}}$ & $51.25(0.9)^{\mathrm{ab}}$ \\
\hline
\end{tabular}

- Mean (Standard Deviation) from 10 rats. Values with different letters in the same

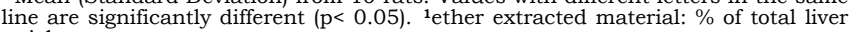
weight. 
Modulation of plasma lipoproteins by dietary lipids, the ratio LDL/HDL is very important in the atherogenesis [13]. In the present work, the values for this ratio were higher in the group fed on lard when compared with the group fed on tambaqui fat (Table 5).

\section{4 - CONCLUSION}

It may be concluded that tambaqui fat is a good dietary source of lipids as a substitute for lard and similar to soybean oil, as far as atherosclerosis risks is concerned.

\section{5 - REFERENCES}

[1] A.O.A.C. (ASSOCIATION OF OFFICIAL ANALYTICAL CHEMISTS), 1995. Oils and fats. Official Methods of Analysis. $6^{\text {th }}$ edition. vol. II. Cap. 41.

[2] AL-SHURBAJI, A.; LARSSON-BACKSTRÖM, C.; BERGLUND, L. EGGERTSEN, G. \& BJÖRKHEM, I. Effect of n-3 fatty acids on key enzymes involved in cholesterol and triglyceride turnover in the rat liver. Lipids v.26, p. 385389, 1991.

[3] BALASUBRAMANIAM, S.; SIMONS, L.A.; CHANG, S. \& HICKIE, J.B. Reduction in plasma cholesterol and increase in biliary cholesterol by a diet rich in n-3 fatty acids in the rat. Journal of Lipid Research. V.26, p. 684-689, 1985.

[4] BOISHIO, A.A.P). Produção pesqueira em Porto Velho. Rondônia (1984-1989) - Alguns aspectos ecológicos das espécies comercialmente relevantes. Acta Amazonica. V.22, p. 163-172, 1992.

[5] CASTElO, F.P; AMAYA, D.R. \& STRONG, F.C. Aproveitamento e características da gordura cavitária do Tambaqui, Colossoma macropomum Cuvier 1818. Acta Amazonica v.10, p.557-576, 1980.

[6] DAYEBERG, J.; BANG, H.O. \& HJORNE, N. Fatty acid composition of the plasma lipids in Greenland Eskimos. American Journal of Clinical Nutrition v.28, p.958-966, 1975.

[7] FOLCH, J.; LEES, M. \& STANLEY, G.H. A simple method for isolation and purification of total lipids from animal tissues. Journal of Biological Chemistry 226: 497-509, 1957.

[8] GARDNER, C.D. \& KRAEMER, H.C. Mono-unsaturated versus poly-unsaturated dietary fat and serum lipids - a metaanalysis. Arteriosclerosis, Thrombosis and Vascular Biology v.15, p. 1917-1927, 1995.

[9] GARG, M.L.; THOMSON, A.B.R. \& CLANDININ, M.T. Effect Of Dietary Fish Oil On Tissue Lipid Metabolism, In: CHANDRA, R.K. (ed.) Health Effects of Fish and Fish Oils. St. John's: ARTS Biomedical Publishers and Distributors Limited, 1989, p. 53-79.

[10] GREen, M.H.; MASSARO, E.R.. \& GREEN, J.B. Multicompartmental analysis of the effects of dietary fat saturation and cholesterol on absorptive lipoprotein metabolism in the rat. American Journal of Clinical Nutrition v.40, p.82-94, 1984.

[11] GUERRA, M.O. \& PETERS, V.M. Morfometria de ratos wistar: peso e medidas corporais. Revista Ciências Biomédicas de São Paulo. V.15, p. 65-74, 1995.

[12] HARRIS, W.S. Fish oils and plasma lipid and lipoprotein metabolism in humans: a critical review. Journal of Lipid Research, v.30, p.785-807, 1989.

[13] HAYES, K.C.; PRONCZUK, A. \& KHOSLA, P. A rationale for plasma cholesterol modulation by dietary fatty acids: modeling the human response in animals. Journal of Nutritional Biochemistry, v.6, p.188-194, 1995.

[14] HUBBARD, R.W.; MEJIA, A. \& HORNING, M. The Potential of diet to alter disease processes. Nutrition Research, v.14, p. 1853-1895, 1994.

[15] KEYS, A.; ANDERSON, J.T. \& GRANDE, F. Serum cholesterol response to changes in the diet. IV. Particular saturated fatty acids in the diet. Metabolism, v.14, p.776-787, 1965.

[16] KONING, A.J. \& MOL, T. The cholesterol content of south african fish oil and its seasonal variation. Fett. Wissens. Technology, v.94, p. 60-63, 1992.

[17] KONING, A.J.; HEARSHAW, K.D. \& MERWE, G. Free and esterified cholesterol in a number of south african fish oils and their corresponding meals. Fett. Wissens. Technolology, v. 95, p. 27-31, 1993.

[18] KRITCHEVSKY, D. Animal products and degenerative disease. Canadian Journal of Animal Science, v.66, p.310, 1986

[19] LIU, C.; HUANG, M. \& HUANG, P. Sources of triacylglycerol accumulation in livers of rats fed a cholesterol supplemented diet. Lipids, v. 30, p. 527-531, 1995.

[20] MAIA, E.L \& RODRIGUEZ-AMAYA, D.B. Fatty acid composition of the total, neutral and phospholipids of the brazilian freshwater fish Colossoma macropomum In: CHARALAMBOUS, G. (Ed.) Food Sciences and Human Nutrition. London: Elsevier Science Publishers B.V., 1992, p. 633-642.

[21] MARINETTI, G.V. Dietary Management of elevated blood lipids. In: MARINETTI, G.V. ed. Disorders of Lipid Metabolism. New York: Plenum Press, 1990, p. 135-168.

[22] McNAMARA, D.J.. Coronary heart disease. In: BROWN, M.L. (Ed.). Present Knowledge in Nutrition. 6 ed., Washington: ILSI, 1990, p. 349-335.

[23] OLIVEIRA, M.R.M. Lipides séricos e hepáticos em ratos tratados com dieta contendo óleo de peixes de rios brasileiros. Araraquara, 1994. 87p. Dissertação de Mestrado Faculdade de Ciências Farmacêuticas. UNESP. SP.

[24] PACKARD, C.J. Plasma lipids an lipoprotein metabolism in the 1990s - what we know and what we need to know. In: BETTERIDGE, D.J. (Ed.). Lipids: current perspectives. London: Martin Dunitz Ltd.,1996, p. 1-20.

[25] SASSEN, L.M.H.; LAMERS, J.M.J. \& VERDUW, P.D. Fish oil and the prevention and regression of atherosclerosis. Cardiovascular Drugs and Therapy v. 8, p. 179-191, 1994.

[26] SMIT, M.J.; VERKADE, H.J.; HAVINGA, R.; VONK, R.J.; SCHERPHOF, G.L.; VELD, G.I. \& KUIPERS, F. Dietary fish oil potentiates bile acid-induced cholesterol secretion into bile in rats. Journal of Lipid Research, v.35, p.301-310, 1994.

[27] SNEDECOR, G.W. \& COCHRAN, W.G., 1980. Statistical Methods. 7 ed., Iowa State University Press, Iowa.

[28] SPADY, D.K. \& DIETSCHY, J.M. Dietary saturated triacylglycerols suppress hepatic low density lipoprotein receptor activity in the hamster. Proceedings National Academy of Science, v.82, p. 4526-4530, 1985.

[29] TAKITA, T.; NAKAMURA, K. \& INAMI, S. Effects of dietary oils which different $n-3$ fatty acid sources and n-3/n-6 ratios on lipid metabolism of rats fed on high cholesterol diet. Bioscience Biotechnology Biochemistry, v.58, p. 695-698, 1994.

[30] VANHANEN, H.T.; BLOMQVIST, S.; EHNHOLM, C.; HYVÖNEN, M.; TORTSILA, I. \& MIETTINEN, T. Serum cholesterol precursors, and plant sterols in hypercholesterolemic subjects with different apoe 
phenotypes during sitostanol ester treatment. Journal of Lipid Research, v.34, p. 1535-1544, 1993.

[31] WILLET, W. Diet and health: what should we eat? Science, v.264, p.532-537, 1994.

[32] WONG, S. \& MARSH, J.B. Inhibition of apolipoprotein secretion and phosphatidate phosphohydrolase activaty by eicosapentaenoic and docosahexaenoic acids in the perfused rat liver. Metabolism, v.37, p.1177-1181, 1988.

[33] YAQOOB, P.; SHERRINGTON, E.J. JEFFREY, N.M. SANDERSON, P.; HARVEY, D..J.; NEWSHOLME, E.A. \& CALDER, P.C. Comparison of the effects of a range of dietary lipids upon serum and tissue lipid composition in the rat. International Journal of Biochemistry and Cell Biology, v.27, p.297-310, 1995.

\section{6 - ACKNOWLEDGEMENTS}

The authors are grateful Dr. Leonides Resende Junior for his assistance and to KATAL for the donation of cholesterol and triacylglycerol determination kits. This work was supported by Conselho Nacional de Desenvolvimento Científico e Tecnológico (CNPq), Coordenação de Pessoal de Ensino Superior (CAPES) and Fundação de Amparo à Pesquisa de Minas Gerais (FAPEMIG). 